\title{
Towards a New Philosophy of Language, Culture and Literacy in Nigeria for National Development
}

\author{
Godwin Okaneme \\ Department of Philosophy, University of Abuja, Abuja, Nigeria \\ Email: godack76@yahoo.com
}

Received 6 July 2015; accepted 26 November 2015; published 30 November 2015

Copyright (C) 2015 by author and Scientific Research Publishing Inc.

This work is licensed under the Creative Commons Attribution International License (CC BY).

http://creativecommons.org/licenses/by/4.0/

\section{(c) (i) Open Access}

\begin{abstract}
Language, culture and literacy are three major components that are necessary for the national development of any country. It is difficult if not impossible to see adequately the functions of language because it is so deeply rooted in the whole of human behavior that it may be suspected that there is little in the functional side of human conscious behaviour in which language does not play a vital part either directly or indirectly. Culture on its part is the sum of the attainments and activities of any specific period, race or people including their implements, handicrafts, agriculture, economics, music, art, religious beliefs, traditions, language and story. Culture is indeed an indispensable part of human conscious existence. Literacy on its part is the ability to read and write. It encompasses a complex set of abilities to understand and use the dominant symbol systems of a culture for personal and community development. This paper critically affirms that the three aforementioned components of language, culture and literacy could be harnessed to ensure national development in the country. It suggests a critical and paradigm shift in the practical use and application of these three major components towards enhanced national development.
\end{abstract}

\section{Keywords}

Philosophy, Language, Culture, Literacy, Nigeria, National Development

\section{Introduction}

Language, culture and literacy are three major ingredients or components that positively aid development in any country. Indeed, they could be said to be unifying factors in a nation's ultimate march towards development and progress. Without these three components being properly situated in a nation, it will be difficult for such a nation to make visible and verifiable progress and in that case, its development will be highly encumbered and en- 
dangered as well.

Language plays major roles in the day-to-day activities of man in the society especially as he tries to interact with his fellow citizens in the society. Its major or primary function bothers so much on communication. A nation without language or languages is utterly inconceivable as such a nation will not make any meaningful impact in world affairs. Language is indeed so deeply rooted in the whole of human behaviour that it may be highly suspected that there is so little in the functional side of human conscious behvaiour in which language does not play a major and critical part. Apart from playing the role of communication among humankind, language also distinguishes man from the other animals as such animals possess the gift of noise not language per se.

According to Ozumba (2004: p. 18),

Language is nothing but human non-instinctual act, it is learnt. Though the disposition to learn language may be a product of instinct, it has its semantic, syntactic, phonetic, morphemic and semiotic dimensions. Language is a means of communicating ideas and thought for our language to be meaningful, it must follow laid down rules of structure. It must be composed of words, which in turn are put into sentences expressing some thought. Language is made up of a repertoire of words called vocabulary and these words are made to constitute the lexical content of the language in question.

Culture on the other hand embraces the sum total or the totality of the attainments and activities of any specific period or epoch, race or people which include their implements, handicrafts agriculture, economic, music, art, religious beliefs, traditions, language and story. Indeed culture could be said to be the sum total of a people's way of life. A people without a culture cannot be conceived for it is a people's culture that critically projects them to others in the world. Culture is indeed a critical, obvious, indispensable and integral part of humankind. It is indeed very synonymous with mankind.

Literacy on its part simply implies the ability to read and write. Literacy is indeed an indispensable aspect of human consciousness as it is solely responsible for human intellectual development and critical growth. A nation whose literal development is questionable cannot be ranked among the most serious-minded nations of the world as knowledge which is said to be power can largely be conveyed and transferred mainly through the vehicle of literacy.

\section{Philosophy: An Excursion into Its Meaning and Usefulness}

Philosophy as a discipline has been and continues to be a curious enterprise. It is indeed a puzzle both to the scholars that study it and even those who stumble into it one way or the other. According to Popkin and Stroll (1993: p. xi),

Philosophy is generally regarded as perhaps the most abstruse and abstract of all subjects, far removed from the affairs of ordinary life. But although many people think of it as being remote from normal interest and beyond comprehension, nearly all of us have some philosophical views, whether we are aware of them or not. It is curious that although most people are vague about what philosophy is, the term appears frequently in their conversation.

According to Nwala (1997: p. 7), no-one definition is adequate or sufficient to express the meaning of philosophy. This is because its meaning has been varied over the course of its history. Moreover, different philosophers have different views on what philosophy is its subject-matter and method. It is not surprising that those who engage in philosophical inquiry do not agree as to the essence of that activity because by its nature, this is bound to be so. This view is largely shared by Barbet (1990: p. 1), Ogundowole (2005: p. 2), Onigbinde (2009: p. 1), Onigbinde (2006: p. 1), Oyeshile and Ugwuanyi (2006: p. 3).

It has been variously explained that the word philosophy comes from two Greek words namely Philo and Sophia which means love of and wisdom respectively. From these two Greek words, we derive the etymological or literary meaning of philosophy which is love of wisdom. It therefore vividly implies that a philosopher is a lover of wisdom. He is one who pursues wisdom for its own sake. The philosopher pursues wisdom and acquires it and puts it into good use for his own good and that of his society. The difference therefore between a philosopher and other scholars of other disciplines or non-philosophers lies in the fact that while the scholars of other disciplines studies other forms of knowledge, the philosopher ultimately goes after knowledge ultimately for its own sake hence the philosopher is ultimately referred to as seeker of knowledge. It may not mean that the philosopher may not venture into other areas of human endeavour, however his greatest preoccupation is seeking 
knowledge for knowledge sake which ultimately is his calling. Indeed it is his greatest pleasure and ambition and he derives his pleasure from doing just that. It is actually what gives him his identity and trademark. In the society, he stands out among the other citizens because he possesses some kind of specialized knowledge which the rest of the citizens do not possess. It is usually referred to as philosophic knowledge.

Philosophy is the specialized branch of study which ultimately seeks to understand, unlock and unravel the mysteries of existence and reality. It tries to discover the nature of truth and knowledge and to find what is of basic value and importance in life. It also examines the relationship between humanity and nature and also between the individual and society, philosophy arises out of wonder according to Aristotle one of the founding fathers of philosophy, curiosity and the desire to know and understand issues even more clearly and coherently. Philosophy is therefore a forum of inquiry, a process of analysis, criticism, interpretation and speculation.

All human beings orient their lives around ideas on what reality is all about. It is such ideas of reality which they formulate that eventually provide a sort of guide for their lives. Philosophy indeed permeates the whole gamut of human existence. It encompasses ideas and ideas they say rule the world. It is an incontrovertible fact that all developmental theories that have led to various scientific breakthroughs in the course of human history and existence came about through ideas and idea is the hallmark of philosophy. The ideas that people live and die for, go to war for and in some cases even take other peoples' lives are all philosophical ideas which they hold tenaciously to. The lives people live and the achievements they make in life whether common or uncommon, tangible or intangible are the result of the philosophy they hold and propagate. Such people may or even may not be conscious of this critical existential reality which is the fact that they are upholding a certain philosophy in life.

Philosophic thought therefore is an inescapable part of human existence. Philosophers are usually engrossed with thoughts about life and existence which other people take for granted more often than not. Such thoughts include "what does life actually mean? Is there life after death? What is man? What can I hope for? Does God exist, what is the best form of government, etc.".

\section{Language, Culture and Literacy: An Appraisal}

\subsection{Language: An Appraisal}

Many scholars in the humanities and social sciences have spent a great deal of their modest research efforts in trying to unearth or unravel the actual meaning of language. According to Ozumba (2004: p. 18), language is a means of communicating ideas and thought. For our language to be meaningful, it must follow laid down rules of structure. It must be composed of words which in turn are put into sentences expressing some thought. Language is made up of a repertoire of words called vocabulary and these words are made to constitute the lexical content of the language in question.

In the words of Anyanwu (2006: p. 1), language is both oral and written and is used in all aspects of a people's life and culture. According to him, language is obviously a defining and an identification feature, with minimum ambiguity for understanding the distinctiveness of human groups at all levels of human society. It easily helps in the location of autonomous units among human collectivities. Language therefore is a veritable tool or means of communication among human species. A world without language is almost inconceivable as absence of language in our world of today that is highly verbally conscious is almost impossibility for philosophers largely regard man as a homo tonguens or a talking being. It is therefore through the medium of language that man expresses himself to the full without reservation. He communicates his state at all times whether he is happy, sad, sober or emotional through language. When he communicates his status, he shares his burdens or emotions. He can only do so through the medium of spoken language and is he is equally understood in that context.

It is in the light of this that Mamza (2010: p. 71) clearly asserts that: language is arguably the most important component of culture because much of the rest of it is normally transmitted orally. It is impossible to understand the subtle nuances and deep meaning of another culture without knowing its language well. Arguing along the same line, Okaneme (2010: p. 93) argues that: Language gives man the ability to organize his thoughts and therefore enables him to collect, sort, relate and record his ideas. It is made up of a complex inventory of all the ideas, interests and occupations that engage the attention of a community.

Other intellectual icons including Ijoma (1988: p. 47), Coplan (1985: p. 203), Greenberg (1971: p. 156), Egonu (1988: p. 59) and Okwuidegbe (2009: p. 127) all allude to the indispensability of language. 


\subsection{Culture: An Appraisal}

Culture remains an issue of uncommon and monumental interest among scholars in the humanities and even social sciences. It has been variously defined by different scholars according to their intellectual bend hence culture as an intellectual phenomenon has many definitions. In the words of Kroeber (1963: p. 132): the culture of the world past and present, form an inter-connected continuum and it is somewhat arbitrary to dichotomize this continuum on the one specific issue of whether particular cultures do or do not have writing and call them civilized or uncivilized accordingly. Culture is simply defined as a way of life of a people of a given area. It virtually encompasses all characteristics and interests of the people as part of their culture.

Culture is more than the arts and literature. In its widest sense and appearance, culture embraces or encompasses all that an individual does or engages himself in from the choice of what to put on, on daily basis to the traditions, beliefs and values of one's family, clan and even community. This definitely and certainly encompasses all manner of artistic expression and human creativity. Culture obviously includes the language we speak, our place and mode of worship, the things that move people emotionally and the sources of critical and conscious meaning in people's lives. Culture therefore embraces and embodies all these human elements and the way they obviously connect to make up one's way of life. It is the whole complex or matrix of distinctive spiritual, material, intellectual, political, sociological and emotional features that characterize a society or a social group.

A living culture is highly dynamic. To that effect, it is not static but always and constantly in motion or in a state of flux. Members of a particular culture are always free to think and a culture consciously grows and develops in response to other cultures and changes that occur within its environment. Culture is indeed an important variable in the matrix of existence for all living beings. It gives people an uncommon existential identity in their onerous quest to assert themselves in their world. It is in the light of this that Anigbo (1988: p. 25), Metuli \& Ojoade (1990: p. 5), New International Webster's Comprehensive Dictionary of the English Language (2004: p. 314), Algbe (2007: p. 241), Obuasi (2007: p. 251), Anyanwu (2006: p. 2), The New Encyclopaedia Britannica (1988: p. 784), Magbemena (2006: p. 186), Iwuchukwu (2006: p. 201), Egonwa (2010: p. 1) and Ikwuegbu (2010: p. 217) all highlight the monumental and uncommon importance and inevitability of culture as a critical and conscious human component in the world.

\subsection{Literacy: An Appraisal}

There are no universal definitions and standards of literacy. Low levels of literacy and education in general can and indeed does impede the social, economic and political development of a country in the current rapidly changing and technology-driven world. The New International Webster's Comprehensive Dictionary of the English Language (2004: p. 743) provides rather a very vague or loose definition of literacy when it defined it as the state or condition of being literate. This definition vague as it is hardly does not capture the real essence nor does it portray to the full the exact import of literacy. However, Dike (2009: p. 2) provides a more detailed definition of what literacy stands for. In his words, "basically literacy is the ability of an individual to read and write. But its broad definition goes beyond that; literacy involves reading, writing, speaking and listening”. UNESCO (2004: p. 13) provides a further leeway to the definition of literacy when it stated thus: "Literacy is the ability to identify, understand, interpret, create, communicate, compute and use printed and written materials associated with varying contexts. Literacy involves a continuum of learning to enable an individual to achieve his or her goals to develop this or her knowledge and potential and to participate fully in the wider society"

Literacy is one of the key indices of a nation's development. High level of literacy is an indicator of a nation's positive development while a low level of development indicates otherwise. It is as a result of this very important factor that many nations of the world channel a great deal of their scarce economic resources into the education of their citizens particularly the youths to make the literacy level in their countries consciously high and also to give their youths a brighter future. By so doing, they help to equip their citizens of youthful age with the right and positives skills to enable them face the future with uncommon courage and rare determination. To some critical-minded citizens, this is the real meaning of youth empowerment which is equipping the youths intellectually in order to face the uncertain world with a great deal of certainty.

\section{The Role of Language, Culture and Literacy in National Development}

Language plays uncommon and significant roles in national development. No one can ever imagine or fathom a 
world without language. The importance of language cannot be over-emphasized in today’s world that is highly communication dependent, in the words of Adedimeji (2010: p. 2), "Like human beings that use it, one basic feature of human language is diversity/dynamism. It is always in a state of flux, moving, changing and coming into contact with its kind". Language therefore is a veritable means of establishing contact, promoting relationships and projecting personal and social identity. Language is very essential to every aspect and interaction in the daily affairs of man. Man uses language to inform people around him about his feelings, desires, aspirations, ambitions, fears and even limitations. Even when there are disagreements among humankind, it is still the medium of language that is employed to see to the amicable resolution of such crises. The same goes for disagreements between communities and even countries.

Culture remains a very unique and important as well as integral part of human existence. It is difficult to think of humanity without culture. Culture points to the pattern of human activity and also the symbols, which give significance to this activity. Culture largely finds representation in various and varied aspects of human consciousness and activities which largely include art, literature, music, language, religion, traditions of a community and knowledge or world views. Different cultures exist in different parts of the world. Differences in cultural patterns are not strange at all. The natural environment largely affects the lifestyle of the people of each particular region or community. Cultures are usually shaped by the lifestyles of people that make up each cultural unit.

The importance of culture is to be located in the simple fact that the cultural values of a community give it an identity of its own. A community gains a unique character and an identity of its own due to the culture of its people. Culture is a shared unique variable among members of a particular community. It is learned from cradle and transmitted from the older generations to the newer or younger ones. For there to be an effective and flawless transfer of culture from one generation to another, it has to be necessarily replicated in symbols, language, art, and religion which serve as veritable means of cultural transfer.

Culture is a strong bond that ties the citizens of a community together. It is the one strong bond which copiously binds the people of the community together hence people usually talk about cultural bond. The customs and traditions that the people of a community follow the festivals they celebrate, the clothes they wear, the food they eat and the relationships they keep are all cultural values that bind people of a community together. Culture is a system of social control which drives people to shape their standards and behaviours. Such cultural values involuntarily become the founding and guiding principles of people's lives. They influence to a very great extent people's philosophies of life and indeed their way of life significantly.

Culture is very critical to the survival of the human race. It embodies in a general sense values, norms and social control. Values are socially shared and socially modified ideas about what is right and wrong, good and bad in society. Values are general ideas. They are broad as well as abstract. They usually vary from one society or community to another and one unique way to study a given society is to examine the inherent values held by its members. Values are important because it is from them that norms or rules of engagement that govern the lives of citizens on daily basis are derived or generated. Norms are derived from a society's overall values or value chain. Values to a large extent determine norms. Social control on the other hand is a means through which the society ensures that its members follow approved norms to ensure peace and harmony in the society. Social control ensures that deviation from approved norms attract due sanctions which serves as a deterrent to citizens who may wish to toe the line of perpetual dissent. A cultureless society can never be imagined as such a community will be deeply prone to orchestrated lawlessness and deep-rooted anarchy.

Literacy on the other hand is arguably the most important aspect of education. Without literacy all other aspects of learning are inconceivable. Literacy critically involves the conscious use of the concepts of reading, writing, speaking, listening and viewing to attain further and improved knowledge. Without the critical acquisition of these aforementioned skills or concepts, there is no chance for anyone to acquire knowledge. Literacy is a consequential aspect of learning. Literacy must first of all occur before any other type of learning can take place and no society can grow and develop without literacy. A literate society is indeed an enlightened society.

Having highlighted all these germane issues, the critical question that arises is what is the role of language, culture and literacy in national development? Beginning with language, it has been established that language is an essential component of human existence. No society can ever function appropriately without the acquisition and use of a language which essentially functions as a medium of communication among its citizenry. Language therefore serves as a strong binding force which unites the citizens. It provides the critical medium of interaction among the citizens of any nation. Language carries with it a bond of love, unity and togetherness that usually 
binds citizens that speak it together. It is indeed a veritable factor of development as nations that are mono-lingual arguably tend to have a faster rate of development than nations that have a multi-lingual linguistic disposition. Development of any nation cannot even be contemplated without language for it is a tangible force that drives any nation's developmental process. This fact is poignantly reiterated by Prah (1993: p. 12) when he succinctly stated that language is the essential matrix and facilitator in the development and growth of culture as a process. It articulates the material transformations in the social process and mediates between humans in their relationship with nature. Language is a powerful force in human and societal development that it can rightly be asserted that without the force of language, development in any nation would be difficult if not impossible to attain.

Culture on its part has variously been described as a way of life of a people which consists of their art, literature, religion, music and aesthetics. Culture is an integral part of man as man realizes himself deeply in his culture. Culture therefore enhances national development a great deal. This view is strongly collaborated by Zuofa (2006: p. 81) thus:

Culture could be used to foster socio-political emancipation, or enslavement, to encourage fundamental enhancement or breakdown of traditional economic structures, and to stall or capitalize societal creativities and innovation. It is also evident that humankind is a product of culture. Culture in this sense constitutes an indispensable element in man's understanding and interpretation of his environment as well as his networks of interpersonal relationships.

Literacy and development are simply inseparable. This assertion is corroborated by the age-long assertion which simply states that knowledge is power. The place of literacy in the general development and enhancement of man and his society is not in doubt.

Literacy encourages the sharing of ideas to a large extent and philosophers and other scholars are of the considered opinion that ideas rule the world. Literacy encourages the cross-fertilization of ideas which enhances national growth among various countries of the world. No nation can develop significantly while majority of its citizens are untutored. It is safe to state that literacy is a virtue while illiteracy is a serious vice; little wonder therefore that many countries of the world both the developed and developing ones channel so much of their human and economic resources in fighting the scourge of illiteracy. For nations that have high literacy levels, development is not difficult to come by while for such nations that has low literacy levels, under-development remain their veritable companion.

\section{Towards a New Philosophy of Language, Culture and Literacy in Nigeria}

Language has been described as one of man's greatest tools for living a meaningful life on planet earth. So unique is language to man that he has been described severally as a talking animal. Language gives man the ability to organize his thoughts coherently. Every nation is readily identified by its language as one of the distinguishing existential traits. While some nations have a monolithic language, others have a plethora of languages. Nigeria is among the nations that have many languages apart from English language which is its adopted lingua franca.

Perhaps one of the issues that deserve more than a passing attention in the nation's language domain is the issue of developing and nurturing a national language for the country. Language is one of the elements that give a national identity to any nation. To say that Nigeria does not have a homegrown national language amounts to belabouring the obvious. From the period of the amalgamation of the Northern and Southern protectorates in 1914 up to the nation's independence in 1960 till now, Nigeria has massively employed the use of a foreign language (English Language) as its official language. This is indeed a far cry from what obtains in some other African countries. In South Africa for example, Afrikaans is one of the recognized languages spoken in the country. It is also massively spoken in Namibia. Over five million people in South Africa speak the language. The language Afrikaans originated as the language of Dutch settlers in South Africa. It is an admixture of English, French, Portuguese and Bantu languages.

Many scholars have come up with suggestions on how to tackle the national language imbroglio in Nigeria. While some have suggested the adoption of the Nigerian version of English Language popularly called Pidgin English as our lingua franca, others suggest that we adopt the components of the three major languages of Igbo, Hausa and Yoruba as the national languages while some others suggest what is popularly called "wazobia", a combination of Igbo, Hausa and Yoruba languages as our official language. There is no doubt that all these sug- 
gestions have their merit but also have their shortcomings as well.

We have language experts in the country and it will not be out of place to suggest that such language gurus should be tasked to come together and fashion out a highly acceptable national language for the country which will attract wide national acceptance. In doing this, such scholars should take due cognizance of the vast ethnic, religious and cultural background that make up this entity called Nigeria. This is to ensure that all vested interests are adequately taken care of. This will obviously down play the unofficial adoption of the three major languages of Igbo, Hausa and Yoruba as the official languages of the country which offends the sensibility of the numerous other ethnic nationalities in the country. This suggestion will no doubt give the nation an all-inclusive, easy-to-learn and homegrown language as its official language. This will obviously bring to a perpetual end the perennial challenges posed by the non-availability of a national language in the country with its attendant negative connotations.

Perhaps another major issue to be considered here is the perennial danger of language endangerment in the country. It has been stressed time and again that some of our indigenous languages have become endangered language species. This must have come about due to the utter neglect of such languages by their owners who adopted a voluntary preference for English Language to the detriment of such local languages. Another very unhealthy development is the muzzling of local languages in primary and secondary schools in the country. More often than not, pupils and students of these schools are prevented from freely expressing themselves in their mother tongues. Such helpless young scholars have various sanctions imposed on them by their teachers for speaking 'vernacular' in class. With such impositions, such young people voluntarily begin to abhor their native languages even in their homes seeing such languages as either irrelevant or unnecessary. Such obnoxious practice is more pronounced in private institutions where the proprietors go the extra mile in trying to impress the parents and would-be ones in order to increase the number of students in their schools. When a child is not taught his mother tongue in his cradle, he will end up being a stranger even in his community when he grows up as he may not be able to speak his language fluently. It is already happening in real life today in the country as we have some of our young boys and girls in the cities who bear native names but can barely speak their native languages. The attitude of hypocrisy of some of our universities is indeed stranger than fiction.

It is quite disgusting as well as frustrating that in some of these universities in the country, no local language is taught while they have departments of French, German and Spanish among others in their various campuses. This is bizarre to say the least. It is worthy of note that it is not foreigners that will develop these local languages but Nigerians who speak them through critical, conscious and painstaking efforts aimed at popularizing them. Every language is dynamic. It is capable of expanding to amazing dimensions or dying out rightly depending on the owners' attitude towards it. Languages grow when they are carefully nurtured and preserved. We must therefore develop a conscious philosophy of propagating and harnessing our local languages to enable them grow and serve the various ethnic nationalities that own and speak them. By so doing, such languages can even be brought to the international arena. When this is consciously done, the issue of language endangerment will no longer be a serious issue as it will fizzle out naturally.

Culture is a major component of people's lives. According to Bamikole (2007: p. 24), "from the ordinary understanding, the word 'culture' means a total way of life of a group of people or community. This way includes the arts, music, modes of dressing, beliefs and practices”. Williams (1967: pp. 273-276) simply amplified the meaning of culture when he stated that:

The word 'culture' in its social and intellectual and artistic senses is a metaphorical term derived from the act of cultivating the soil. The cultivation of the mind was seen as a process comparable to the cultivation of the soil hence, the early meaning of 'culture' in this metaphorical sense which is centered on a process "the culture of the mind" rather than an achieved state.

Culture is usually transmitted from the old people to the young ones. Traditionally, it is rightly said that the old people are the custodians of culture and they transmit same to the younger generation. However, of late in Nigeria, the country has witnessed massive cultural retrogression among the various ethnic nationalities that make up the Nigerian state which has become a real source of embarrassment to both the successive governments and the entire citizenry. It is too strange to see Nigerians abandon their culture for foreign ones. This is indeed a sure manifestation of unpatriotic attitude. Nigerian has indeed a rich reservoir of culture which can portray the nation in real good light. Many aspects of Nigerian culture can compare favorably with the cultures of other parts of the world. Nigerian music for example are world beaters and are even more popularly accepted in 
the world arena than music from the Western world. Other critical examples abound.

Perhaps many reasons could be adduced for the current embarrassing cultural retrogression the nation is witnessing in its history today. Perhaps the worsening economic situation in the country today has voluntarily encouraged the massive abandonment of our various noble cultures as life has become a rat race where people struggle vigorously on daily basis for survival. People now cheat, kill, kidnap, tell lies and defraud both government and their fellow citizens in order to survive on daily basis. Unfortunately, greed which many agree is alien to our culture has got a better hold of many of the citizens that having and showing love and being charitable to the less fortunate members of the society has almost become a fairy-tale. Unfortunately greed has pushed many Nigerians to get involved in primitive acquisition of wealth which is antithetical to our culture. Many citizens are involved in accumulating wealth they and their entire families cannot spend in their entire lifetime. Kleptomania has fully been entrenched in the nation's governance system and structure that people now aspire for political power mainly for pecuniary economic reasons instead of aspiring to serve to better the lives of the masses and ultimately developing the nation. Ultimately, the culture of self-contentment has effectively been replaced by that of self-enrichment, corruption, armed robbery, embezzlement of public funds, kidnapping and all kinds of deviant behaviours. To state that the nation is facing a cultural collapse is just belabouring the obvious.

One other major challenge of culture in Nigeria which has helped in no small way in robbing the nation's culture of its shine is the issue of culture contact. By that I mean the contact between the nation's culture and that of other cultures of the world particularly the Western cultures. Nwala (2006: p. 31) clearly captures this particular point and asserts that when two cultures interact, there are bound to be interactive consequences for both. Our culture has been the worst hit in terms of its contact with other cultures particularly western culture. Our deeply cherished culture of communalism which is the hallmark of African brotherhood and philosophy is fast being replaced by the Western philosophical mode of individualism. Little wonder therefore that being our brothers keepers which is a time-honored existential philosophy of life in the country is becoming a fairy and strange tale to most people in the country today. People especially the less fortunate ones nowadays suffer and die with their problems despite crying out for help from the citizens while struggling with various life-threatening ailments. Unfortunately individualism cannot work here like it works in the West because of manifest systemic differences. In the West, they have well-organized social systems that helps to take care of the needs of their people. Sadly enough, we manifestly lack such social systems here in the country to say the least.

It is therefore envisaged that there should be a new philosophy of culture in the country to halt the present cultural retrogression the nation is witnessing. This has become manifestly expedient as culture and national development are highly compatible and complement each other. No nation can develop if it allows its cultural heritage to erode and disappear from the surface of the earth just like that. There should be a deliberate philosophy of cultural retrieval, renewal and revival as our cultures are fast disappearing and the genuine fear among some concerned citizens is that if this is not halted now, in time to come, there may not be any identifiable culture in any part of the country. We are people who are culture-bound and culture tied as well. What accounts for the present near societal decay in the nation is the voluntary neglect of the nation's rich cultural heritage and if we rationally address this malaise, the nation will certainly experience a swift and rapid cultural revival in the country.

The issue of literacy in the country raises serious curiosity whenever it is mentioned. Nations of the world are rated in international circles by their literacy level. It is not a glorifying issue to have a country with a high preponderance of its citizens having very low literacy level. Unfortunately and sadly too, that seems to be the case with our country at the moment. The gloomy and very worrisome situation of our literacy level was appropriately captured by the former Minister of State for Education, Chief Nyesom Wike two years ago at a ministerial briefing to commemorate the 2013 International Literacy Day. According to him, Nigerian adult illiterates have increased from 25 million in 1997 to 35 million in 2013. He said Nigeria had over 10.5 million children out of school which according to him is embarrassing to the nation. (Source: Vanguard Newspapers, September 11, 2013).

Perhaps it can be stated that the above revelation, startling as it is, is no good news at all to discerning Nigerians. Adding his voice to this gory phenomenon, Dike (2009: p. 1) says that:

One of the major challenges facing Nigeria today is how to reform its education sector and train enough high quality manpower to develop the nation. A lot has been said about revamping the nation's falling standard of education but the leaders have not taken appropriate actions to improve the situation. One of the problems caused by the neglect of education is the overcrowded and chaotic classrooms and Nigeria's dwindling literacy rate. 
Olanrewaju (2008) makes it even clearer when he opined that there is no iota of doubt that the level of development in a country is directly proportional to the literacy level. The literacy rate of Nigeria dropped from 62 percent in 1992 to 52 percent in 2006 . This implies that the illiteracy rate in the country is 48 percent. It also means that rather than improving on the literacy rating, Nigeria keeps on retrogressing. Many factors are said to have voluntarily aided the country's dwindling literacy rate. One of such factors that people especially stakeholders in the education sector readily point to is the utter neglect of libraries in the country. This fact is corroborated by Igwe (2011: p. 4) asserts that:

Libraries have a historic mission of fostering literacy and learning. The relegation of that vital institution in recent decades is indeed a matter of great sadness. Libraries, learning and reading can and do change lives and they have a role to play in determining the future of our society. Libraries are vital to education and research has shown that current lower levels of proficiency in reading are due to underfunding of libraries and their services.

The low level of reading habits and culture among Nigerian citizens is caused by so many other factors. These factors are well catalogued by Gbadamosi (2007: p. 5) who listed them to include:

- Change in Nigeria's value system. The quest for material wealth has eroded the interest for the search for knowledge.

- Economic hardship that is prevalent in many homes. Most parents manage to pay their wards school fees and forget about buying books for them.

- Astronomical prices of books and other information materials have put them out of the reach of the masses. Coupled with high cost of books is poor avail ability of indigenous books owing to the fact that local authors are not encouraged to write books.

- Also cost of publishing books is very high. Indigenous writers are not motivated as they may not be able to finance the high cost of book publishing.

- Advent of home videos, film houses and other electronic gadgets.

The way out is to fund education vigorously and appropriately in this country. Though it is a truism that education is costly, it is still cheaper than ignorance as many people will readily agree. We must understand that education is the bedrock of development for countries that wish to move forward in all ramifications. Therefore the issue of poor funding of the educational sector which has been a recurring decimal in the country should quickly be addressed. Reviving the interest of the citizens particularly the youths towards reading may also help in improving the literacy rate in the country. This can be done in the form of providing incentives like prizes for debate, writing, quiz and other competitive competitions in schools across the length and breadth of the country. This can actually arouse the intellectual consciousness and dexterity of the young ones towards academic and educational inclination.

Government can also do well to motivate the teachers at all levels from the primary to the tertiary levels to enable them give their best in the noble job they do. This is very important as a poorly motivated teacher is a serious minus to the educational sector as he/she cannot offer the best services needed to enhance teaching and learning. Government should also take due cognizance of the fact that the frequent and incessant strikes that occur in the educational sector at all levels is a serious set-back on the constant efforts being made to improve the country’s literacy level. To this end, government should do all it can to ensure that agreements entered into with the various unions in the educational sector are honored by faithfully implementing them to prevent the frequent labour unrests that has characterized the educational sector at all levels for some time now. Incessant strikes in the educational sector do not generally portray the nation in good light. However, it must also be pointed out that the labour leaders in the education sector should adopt a more positive and patriotic approach towards its relationships and interactions with the government and should see government as serious stakeholders in the nation's educational industry. The era of perpetual and perennial mutual suspicion between labour leaders in the education sector and government should be over for good at least for the sake of harmonious relationship.

\section{On National Development}

Development is one topical and critical issue that has engaged the attention of philosophers as well as social scientists over the years because of its uncommon importance to humankind. Development as a theoretical concept has over the years been entrapped in definitional pluralism or what can simply be described as multiplicity 
of definitions. According to Bamikole (2007: p. 26)

In modern and contemporary times, the word 'development' has been used to distinguish nations- some are developed, some are developing and others are underdeveloped. The idea behind these distinctions is based on such indices like the economy, industrial technology and other material conditions. Just like Marx's materialistic conception of history, the substructure of development is economic, while the superstructure are such things like politics, religion and culture.

For the renowned scholar Ade Ajayi (2013: p. 3), development may have a narrow or broader signification. He says:

As to the definition of development we may distinguish between a narrow and a broader signification. Initially, development was taken to mean essentially, growth in the Gross National Product (GNP), increase in the wealth available to the state and within the state. We have seen how, without an increase in productivity at home, international events affecting the price of crude oil suddenly increased the wealth available to the state without enhancing the standard of living of the ordinary citizen. The same international pressures can cause a sudden or progressive devaluation of the currency such that more money buys fewer goods, and the impoverishment of the citizenry is deepened.

For Mclean and McMillan (2003: p. 148), development is a normative concept referring to a multi dimensional process. Some people argue that development must be relative to time, place and circumstance and dismiss any universal formula. For Chaturvedi (2006: p. 84), development is a process of social, economic and political change usually associated with the Third World, so-called 'developing nations'. Often based upon a specifically Western model of development, it signifies the emergence of industrial capitalism and a competitive political system. Rodney (1972: p. 6), Anjov (2006: p. 176) and Chukwuokolo (2008: p. 111) all seem to agree on the many-sided nature of development, while Nduka (2006: p. 4) and Elaigwu (2005: p. 444) both see development as a highly sought-after term, though meaning different things to different scholars.

Having talked about development in a fair detail, let us delve into the major concept of national development. National development can be explained to mean the expansion and growth of people in an area or government. It could also be taken or seen as development and provision of infrastructural facilities in a nation such as roads, schools, rails, hospitals, sea and air ports, power and water supply and so on. Put in another way, development is the expansion and growth of people under a government. It could also be defined or described as the ability of a country to improve the social welfare of the people through the provision of social amenities likes quality and affordable education, potable water, good and efficient transportation infrastructure, good and affordable Medicare and efficient and workable social security. The concept of national development which encompasses economic, social and political development brings about valuable and positive changes in the state which ultimately help in the improvement of the overall living standards of the people as it helps to create employment opportunities for the youths and reduces poverty and crime to the barest minimum.

It will amount to belabouring the obvious for one to assert that Nigeria has not been very fortunate in her arduous march towards national development since her political independence in 1960 till date. The nation has been foisted with poor and near-uneventful political leaders from her independence till date. Even the military that ruled this country for a greater period of time before eventually handing over power to the civilians in 1999 did little to stop the tide of progressive retrogression in the developmental trend in the country little wonder Achebe (1983: p. 2) was very emphatic when he stated unequivocally that the trouble with Nigeria was simply and squarely a failure of leadership. The nation's chequered history has only been aggravated by poor political leadership across the length and breadth of the entire country who perhaps see political offices especially the elective and appointive positions as an opportunity to amass wealth and further impoverish the nation with brazen impunity, perhaps the citizens will only remember the concept of national development in Nigeria with regret as many feel short-changed by the ruling class at every level.

\section{Conclusions}

This paper has taken a critical look at the tripartite issues of language, culture and literacy. It agrees totally that language is an indispensable aspect of human existence. It is almost impossible to think of humankind without language as such scenario will be existentially meaningless. It is language that gives identity to humanity and it 
is the same language that adds colour and candor to the world. Unfortunately, many local languages in the country have suffered neglect and are in danger of going extinct. This paper advocates for a language revolution towards strengthening the local languages in the country as a matter of deliberate governmental policy.

Culture on its part has been deliberated upon extensively in the course of this paper and has been described as a way of life of a people which largely encompasses their art, music, literature, language, festival and religious beliefs. It has been highlighted in the paper that culture contact between the various cultures in the country and Western culture has not benefitted the nation's cultures as they have suffered the harmful effect of being sub zoomed by the Western culture hence we have serious cultural aberrations now in many ethnic nationalities in the country which has ultimately resulted in serious cultural erosion in the nation which is not in the nation's best interest.

Literacy on the other hand implies the unfettered ability to read and write. However, it has been established in the paper that literacy goes beyond the traditional concept of reading and writing to include the ability to speak, listen and apply knowledge to the day-to-day activities of man hence it has been said that literacy involves a continuum of learning to enable an individual to achieve his or her life goals, to develop his or her knowledge and potential and to participate fully and actively in the wider society. It is in the light of this that the paper bemoans the dwindling literacy rate in the country and believes that it is dangerous to have a high number of unlettered and untutored citizenry and therefore made some critical suggestions to address the damaging anomaly.

Finally the hallmark of this paper is applying philosophical principles to the tripartite issues of language, culture and literacy in the country. It is the conviction of the paper that there should indeed be a paradigm shift in our national attitude towards these three important concepts because of their unparalleled importance to the nation's growth and development. The paper has indeed highlighted the critical and philosophical importance of these concepts and therefore canvasses for a new way of harnessing them to enable them play their envisaged roles in the national development of the country. This is very important because one cannot do the same thing over and over again and expect to achieve a different result.

\section{References}

Achebe, C. (1983). The Trouble with Nigeria. Enugu: Fourth Dimension Publishers.

Adedimeji, M. A. (2010). Language Question and the Constitutional Challenges of Development in a Multilingual Country. Journal of Research in National Development, 8.

Ajayi, J. E. A. (2013). The Role of the Academic in the Development of Nigeria. In Issues in National Development, ASUU NDC Lecture Series, Vol. 1. Ibadan: Academic Staff Union of Universities.

Algbe, A. (2007). Language: A Tool for Preservation and Transmission of Cultural Heritage. Journal of Nigerian Languages and Culture, 9,

Anigbo, O. A. C. (1988). Multiculturalism: The Nigerian Experience. In I. T. K. Egonu (Ed.), African Perspective in World Culture. Owerri: Vivians and Vivians Publishers.

Anjov, K. T. (2006). Philosophy and Human Situation: Issues of Development in Africa. In I. Odimegwu (Ed.), Philosophy and Africa. Amawbia: Lumos Nig. Ltd.

Anyanwu, U. D. (2006). Language, Culture and Globalization. Journal of Nigerian Languages and Culture, 8.

Bamikole, L. O. (2007). Culture and Development in Africa. In T. Ebijuwa (Ed.), Philosophy and Social Change. Ibadan: Hope Publications Ltd.

Barbet, A. H. (1990). Mastering Philosophy. London: The Macmillan Press Ltd. http://dx.doi.org/10.1007/978-1-349-20916-3

Chaturvedi, A. K. (2006). Dictionary of Political Science. New Delhi: Academic (India) Publishers.

Chukwuokolo, C. J. (2008). Democracy in Nigerian Development. In I. Odimegwu (Ed.), Nigerian Democracy and Global Democracy. Awka: Fab Educational Books.

Coplan, J. (1985). Speech and Language Development. Pediatric Annals: A Journal of Continuing Pediatric Education, 14.

Dike, V. E. (2009). Tackling Nigeria's Dwindling Literacy Rate. The Nigerian Village. www.nigerianvillagesquare.org

Egonu, I. T. K. (1988). Indigenous and Foreign Languages in Africa: Their Role in African Development. In I. T. K. Egonu (Ed.), African Perspectives in World Culture. Owerri: Vivians and Vivians Publishers.

Egonwa, O. D. (2010). Linguistic Pluralism, Cultural Divergences and the Nigerian Project. Journal of Nigerian Languages and Culture, 12.

Elaigwu, J. S. (2005). Nigeria Yesterday and Today for Tomorrow. Jos: Aha Publishing House. 
Gbadamosi, T. (2007). "Library Reading Culture and Students” Academic Performance in Secondary School in Oyo State. Middle Belt Journal of Library and Information Science, 7, 42-58.

Greenberg, J. (1971). Language, Culture and Communication. Stanford: Stanford University Press.

Igwe, K. N. (2011). Reading Culture and Nigeria’s Quest for sustainable Development. Library Philosophy and Practice (E-Journal Online), Paper 482.

Ijoma, C. P. (1988). Communication, Language and the Arts. In I. T. K. Engonu (Ed.), African Perspectives in World Culture. Owerri: Vivians and Vivians Publishers.

Ikwuegbu, F. N. (2010). Art and Culture in Society: Veritable Tools for Sustainable Development. Journal of Nigerian Languages and Culture, 12.

Iwuchukwu, R. C. (2006). Gender, Culture and Traditional Practices in Igbo Land. Journal of Nigerian Languages and Culture, 8.

Kroeber, A. L. (1963). An Anthropologist Looks at History. Oakland, CA: University of California Press.

Magbemena, J. (2006). Oral Literature: An Instrument for Cultural National Orientation in the Face of Globalization. Journal of Nigerian Languages and Culture, 8.

Mamza, A. J. (2010). Pottery (Ceramics) and Culture in Nigeria: Problems and Prospects. Journal of Nigerian Languages and Culture, 12.

Mclean, I., \& McMillan, A. (2003). The Concise Oxford Dictionary of Politics. Oxford: Oxford University Press.

Metuli, E. I., \& Ojade, O. (1990). Nigerian Cultural Heritage. Jos: Imico Publishers.

Nduka, O. (2006). The Roots of African Underdevelopment and Other Essays. Ibadan: Spectrum Books Limited.

Nwala, T. U. (1997). A Modern Introduction to Philosophy and Logic. Nsukka: Niger Books and Publishing Co. Ltd.

Nwala, T. U. (2006). The Concept of Traditional African Philosophy. In M. Dukor (Ed.), African Philosophy and Pathology of Godhood and Traditionalism. Lagos: Essence Library.

Obuasi, I. (2007). Culture Crises in Our Youths: A Result of Linguistic Alienation? Journal of Nigerian Languages and Culture, 9.

Ogundowole, E. K. (2005). The Notion of Philosophy. In J. Unah (Ed.), Philosophy for All Disciplines. Lagos: Promocomms Ltd.

Okaneme, G. (2010). Igbo Culture and the Forces of Modernism. Journal of Nigerian Languages and Culture, 12.

Okwuidegbe, L. F. (2009). Language, Culture and Justice: Some Misconceptions and Barriers to National Growth. Journal of Nigerian Languages and Culture, 11.

Olanrewaju, S. (2008). Literacy Day: Impact of Literacy on Development. Nigeria Tribune, September 25, 2008.

Onigbinde, A. (2006). Philosophy and the Rest of Us. Ibadan: Frontline Books.

Onigbinde, A. (2009). What Is Philosophy? Ibadan: Frontline Books.

Oyeshile, O. A., \& Ugwuanyi, L. O. (2006). Elements of Philosophy and Logic. Benin: Timeless Publishers.

Ozumba, G. O. (2004). Introduction to Philosophy of Language. Ibadan: Hope Publications Ltd.

Popkin, R. H., \& Stroll, A. (1993). Philosophy. Oxford: Linacre House.

Prah, K. K. (1993). Mother Tongue for Scientific and Technological Development in African. Berlin: DSF.

Rodney, W. (1972). How Europe Underdeveloped Africa. London: Bogle-L’Ouverture Publication.

The New Encyclopaedia Britannica (1988). The New Encyclopaedia Britannica (Vol.3, 15th ed.). Chicago: Encyclopedia Britannica Inc.

The New International Webster's Comprehensive Dictionary of the English Language (2004). Florida: Trident Press International.

UNESCO Education Sector (2004). The Plurality of Literacy and Its Implications for Policies and Programs: Position Paper. Paris: United Nationals Educational, Scientific and Cultural Organization.

Williams, R. (1967). Culture and Civilization. In P. Edwards (Ed.), Encyclopedia of Philosophy (Vol. 2,). New York: The Free Press.

Zuofa, C. C. (2006). Women and Culture in a Globalized World: Educational Implication in Nigeria. Journal of Nigerian Languages and Culture, 8. 